\title{
Judicial Jurisdiction According to the United Nations Convention Against Corruption and its Application to the Iraqi Medical Sector
}

\author{
Sarmad Amer Abbas \\ Assist. Prof., University of Babylon/Faculty of Law/Iraq
}

\begin{abstract}
There is no doubt that corruption is a growing scourge in all countries due to its direct negative impact on the development of societies and limiting their development. It has also become a phenomenon with social, economic and political aspects. Combating it does not require the concerted efforts of one state institutions only, but rather the necessity for states to cooperate with each other to curb administrative and financial corruption, Since 1996, international anti-corruption conventions have served to raise political commitments to fight corruption and have defined basic international standards and practices to tackle corruption. The medical sector in Iraq suffers from corruption in its various health and administrative sectors.
\end{abstract}

Keywords: Judicial jurisdiction, Corruption, application, medical sector.

\section{Introduction}

Notwithstanding a surge in awareness and a plethora of international initiatives, many hurdles remain on the road towards a corruption-free world. To start with, there is no agreement as to what exactly constitutes corruption ${ }^{1}$. Different countries and actors apply differing definitions. Even where agreement exists as to a corrupt act, jurisdictional problems may impede the prosecution of such acts. Moreover, even after a successful legal challenge of corrupt acts, the recovery of assets needs to overcome several legal and logistical hurdles in order to be successful. In addition, the link between corruption and good governance, and between corruption and human rights, remains the subject of intense debate ${ }^{2}$. Iraq has continued the constitutional embrace of international law over the past 15 years by making new international commitments, including joining the United Nations Convention against Corruption. As the United Nations Secretary-General recently noted, the agreement promotes "the shared goals of good governance, stability and prosperity for the international community" and disrupts money laundering, organized crime, and theft of public funds. Iraq took a number of steps in accordance with these goals that led to, and shortly after, accession to the Anti-Corruption Convention. They included, for example, developing and maintaining "coordinated anti-corruption policies", such as issuing an antimoney laundering law, issuing public procurement and investment laws, issuing a law mandating disclosure of assets by senior government officials, reinforcing the responsibilities of Article 5 of United Nations Convention against Corruption. In addition, the state has established and maintained "bodies, as appropriate, that prevent corruption," such as the Integrity Commission, which has investigated thousands of corruption cases since 2004. The health sector in Iraq lives in the midst of an intractable crisis that has worsened in recent years in a country that does not know stability for several reasons that vary but are closely related to the political will of the country's rulers ${ }^{5}$. The health care system in Iraq suffers from several diseases that have decayed its body, such as the permanent shortage of medicines and the unavailability of medical staff.

The Connection between Corruption and Human Rights: When several global and regional treaties to combat corruption were adopted in rapid succession. Regarding the emergence of anti - corruption international legal standards, the Chief of Crime Conventions Section of the United Nations Office on Drug and Crimes (UNODC) maintains that: "the gradual understanding of both the scope and seriousness of the problem of corruption can be seen in the evolution of 
international action against it, which has progressed from general consideration and declarative statements, to the formulation of practical advice, and then to the development of binding legal obligations and the emergence of numerous cases in which countries have sought assistance from other countries in investigating and prosecuting corruption and in tracing, freezing, confiscating and recovering proceeds of corruption offences."Bribery and embezzlement involving public officials diminishes the enjoyment of a human right. Any specific corrupt act is considered a violation or diminution of human rights.

Accordingly, "Corruption" and "bribery" Corruption and bribery are two terms often mistaken for one another or used interchangeably as they have very similar meanings. However, it is important to understand the differences between the two so that businesses can effectively manage, mitigate or hopefully prevent the problems they cause. And the Corruption,is not a technical term; it is not considered a criminal offence in most criminal codes around the world and it also does not have a legal definition in most international treaties ${ }^{6}$. The most common definition is that used by the NGO Transparency International, according to which corruption is the abuse of entrusted power for private gain. Such abuse may happen on the level of day-to-day administration and public service ("petty corruption"), or on the high level of political office ("grand corruption"). These terms do not mark a legal distinction but merely describe variations of the same theme. Often, a particular scheme of corruption permeates the various levels of public administration, and thus links both forms of corruption. Because of the growing power of large corporations and non State actors such as FIFA, the abuse of obligations arising from private law-in a "private" principal-agent relationship-is also increasingly qualified as corruption. The relevant criminal offences are active and passive bribery, criminal breach of trust, graft, illicit enrichment, and so on. In the private sector, offences include anticompetitive practices and regulatory offences. This is not about any (new) human right to a corruption-free society. Such a right is neither recognized by legal practice nor is there a need for it. Rather, corruption affects the recognized human rights as they have been codified by the UN human rights covenants. In practice, what is most often affected are social rights, especially by petty corruption. For example, corruption in the health sector affects the right of everyone to the highest attainable standard of health (Article 12 ICESCR); in the education sector, the right to education (Article 13 ICESCR) is at issue. But also the classical liberal human rights may be undermined by corruption: If a prisoner has to give the guard something in return for a blanket or better food, then the prisoner's basic right to humane conditions of detention (Article 10 ICCPR) is affected. If - as most observers tend to think - the current surge in human trafficking is made possible and facilitated primarily by corruption that induces police and border guards to look the other way, then this affects the human right to protection from slavery and servitude (Article 18 ICCPR). Obviously, corruption in the administration of justice endangers the basic rights to judicial protection, including the right to a fair trial without undue delay (Article 14 ICCPR). In the case of grand corruption and foreign bribery, however, the implications for human rights - such as the effect of nepotism on the right to equal access to public offices (Article 25(a) ICCPR) are less clear.

The most important principles related to the implementation of the United Nations Convention are as follows:

1. The agreement is a binding legal instrument for the states parties, and the failure of the state to implement it entails its international responsibility. Article 66 of the agreement allows for the settlement of disputes between the states parties regarding the interpretation of the agreement and its application through arbitration. If the states parties are unable to agree to arbitration, the dispute may be referred to a court. International justice.

2. The implementation of the agreement shall be through the adoption of a set of legislative and administrative procedures to put the state's commitment into practice.

3. The implementation of the convention by the national judge shall be through the frameworks laid down by national legislation that explain how to implement the convention and clarify the implementation procedures.

4. The obligation to implement the agreement does not undermine the respect for the national sovereignty of the states parties, including the exclusive exercise of the jurisdiction over their territory in all prosecution and punishment procedures, unless the mechanisms of international judicial cooperation allow for some kind of joint investigation. 
Preventive Measures: It is a set of public policies aimed at preventing corruption and states must implement or activate them. Among the most important policies mentioned in the agreement are:

1. Establishing independent bodies responsible for combating corruption and cooperating with states parties to the convention,

2. Spread anti-corruption awareness

3. Establish codes of conduct for public employees and private sector employees with the aim of enhancing integrity and responsibility.

4. These measures also include the establishment of systems and regulations requiring public officials to disclose their earnings from work and any other external activities.

5. Regulating public procurement in addition to enhancing cooperation between law enforcement agencies and private sector entities,

6. It should be noted in this regard that the agreement also emphasized the role that civil society and civil organizations play in the field of prevention and preventive measures.

Criminalization and enforcement: Chapter Three of the Convention consists of twenty-eight comprehensive articles. The importance of this chapter is due to its relevance to the acts criminalized according to the convention. Accordingly, all states parties must adopt "all the legislative and other measures that may be necessary to criminalize these acts," when they are committed intentionally. This chapter also deals with law enforcement procedures. The convention lists legislative measures to criminalize a number of acts, including but not limited to; A public official promised an undue advantage in return for performing an act or abstaining from it, or seeking or accepting a public official for an unworthy advantage, and the bribery is considered one of the most criminal and most dangerous acts, and the matter is equal in the case of bribing a public official affiliated to the state party, or bribing a foreign public official, or An employee of an international public institution as long as the purpose behind granting him such advantage is to obtain an undue benefit or advantage related to the work of that employee concerned.

What applies to the seeking or acceptance of advantage by a public official applies to the embezzlement of property, its squandering, or its diversion in one form or another.
The convention also criminalizes the exploitation of the actual influence of the public office, and obligates states to take the necessary legislative and other measures to criminalize the public official's intention to abuse and exploit the public office.

Trial procedures and protection of witnesses, informants and experts: It is legally established that the procedures for any trial must be conducted in accordance with the fair trial standards established by international human rights covenants, which are affirmed by almost all state constitutions, and that conviction is only made with sufficient evidence that reaches a stage beyond reasonable doubt, and that such a trial Its existence is only conceivable if there is sufficient evidence that is legally acceptable, and that this evidence needs procedural protection, otherwise it will lose justice. * On the other hand, the necessary measures must be taken to protect witnesses, and here comes the issue of witness protection to take on growing importance, especially when it comes to crimes related to money, and Article (32) of the Convention dealt with the issue of protecting witnesses and experts, while Article (33) dealt with Of the United Nations Convention against Corruption, protection of whistleblowers and those in a more dangerous situation than witnesses; This is because the amount is the source of the first information about the alleged crime, and this puts the amount in a situation where it needs legal protection during and after the litigation procedures. In order to achieve the goals aimed at by the convention, articles (37-38-39) deal with aspects of cooperation with law enforcement authorities on the one hand, and the cooperation of these authorities with each other on the other hand. Among the forms of corruption is the employee's interference in the safety of more or more government tenders or the abuse of office influence in obtaining rights for others at a low price and deliberately damaging state funds, which is one of the crimes of gross negligence. General No. 19 of 2008 due to its attachment to public money and its preservation, and in accordance with Article 341 of the Iraqi Penal Code No. 111 of 1969, as amended, every employee or person assigned to a public service who causes a serious error to inflict serious damage on the funds and interest of the entity in which he works or is related to it by virtue of his position or With the money or interests of the people entrusted to him if this resulted from gross negligence in performing his job or from abuse of authority or from a serious breach of his job duties, and other laws that deal with cases of administrative and 
financial corruption, the Financial Supervision Bureau Law, the State Personnel Discipline Law, the Money Laundering Law and the Informer Reward Law And the law controlling smuggled money, which is prohibited from circulating in the local markets. After 2003, a lot of legislation was issued dealing with corruption, including the Coalition Provisional Authority Order (55), (57) and (77) for the year 2004 and the formation of the Integrity Commission and the departments of general inspectors in the ministries to deal with cases of administrative and financial corruption to regulate the work of the Integrity Commission and indicate its functions, tasks and powers that are It enables it to perform these tasks in order to raise the level of integrity, preserve public money, fight corruption, and regulate the relationship between them and other regulatory agencies, and based on the provisions of Article 102 of the Constitution, this Integrity Commission Law No. 30 of 2011 was enacted (11), where Article (1) was considered The corruption case is the criminal case that is being investigated in connection with one of the crimes that violate the duties of the job, which is bribery, embezzlement, employees overstepping the limits of their jobs, and any of the crimes stipulated in Articles (233, 234, 271, 272, 275, 276, 290, 293 and 296) of the Penal Code No. 111 of the year 1969 amended and any other crime in which one of the aggravating circumstances stipulated in paragraphs (5, 6 and 7 of Article 135) of the effective penal code amended by Section (6) of the Organic Law issued by the dissolved Governing Council Attached to the dissolved Coalition Provisional Authority Order in Iraq No. 55 of 2004, where the Iraqi legislator added crimes that breach the course of justice, considering the judiciary as a safe haven to preserve the rights, lives, honor and money of people, as it considered the crime of mediating before the judiciary as corruption crimes, where every employee or taxpayer is punished with imprisonment. In a public service that mediated with a judge or a court in favor of or to the detriment of one of the litigants, and in Article (234) the issuance of a decision that was proven to be unlawful and was the result of mediation. Judicial rulings are considered the title of the judicial truth. Corruption crimes, as Article (271) stipulates that every employee or person charged with a public service is assigned to arrest a person or guard a person who is arrested or detained or detained or imprisoned or accompanying or transporting any of them. Escaping is punishable by imprisonment for a period not exceeding ten years if the convict is sentenced to life or temporary imprisonment, or if he is accused of a felony punishable by death, and the penalty is imprisonment in other cases and in Article (272) of the Penal Code. Punish with imprisonment or a fine whoever is charged with guarding an arrested, detained or arrested person, accompanying him or moving him and causing one of them to escape. The Integrity Commission Law considered the crime of forgery stipulated in Article 290 of the Penal Code No. 111 of 1969, as amended, which stipulates that (Whoever carries an employee and is assigned to a public service while recording a report is within the competence of his job, either by impersonating another person's name) Or by acting in a capacity that he does not have, or by reporting false facts, or by other means to record or prove an incorrect fact regarding a matter that the document would prove to be proven by the legislator as the legislator considered as one of the corruption cases that the employee or the person charged with a public service issued one of the aforementioned papers with the knowledge that the one for whom it was issued He has assumed a false name or a false personality, as well as Article (296) of the Penal Code considered a crime of corruption that punishes with imprisonment whoever is legally mandated to keep books or papers subject to the control of the public authorities, and he writes in them things that are not true. It is possible or omitted to record true matters in it, and that would have deceived the aforementioned authorities and made them into a mistake and any other crime in which one of the aggravating circumstances provided for in paragraphs 5 , 6 and 7 of Article 135 of the Penal Code in force.

More than $50 \%$ of the money allocated to building hospitals in Iraq has been wasted, indicating that huge sums of money were spent to build 15 to 20 large hospitals, of which only 4 hospitals entered service. And the reality in Iraqi hospitals in light of the Corona virus crisis is that Iraqi hospitals are a hotbed of transmission of infection and the spread of the epidemic between sick people and health personnel.

International Cooperation: Under Chapter Four of the Convention, states parties must assist each other in combating corruption, and this chapter provides standards for mutual legal assistance, and cooperation comes in the form of extradition, mutual legal assistance, transfer of judgments of persons, criminal procedures and law enforcement cooperation, which encourages Also, cooperation in civil and administrative matters. Likewise, member states must, in accordance with this chapter, take the necessary measures that would support tracking, freezing, seizing and confiscating proceeds of corruption. 
Asset Recovery: Chapter five is one of the basic principles of the agreement, as the recovery of assets obtained from incidents of corruption is a very important issue, especially for developing countries where corruption rates are increasing.

The agreement includes the essential provisions that establish specific measures and mechanisms for cooperation with the purpose of recovering assets while preserving flexibility in recovery procedures that may be justified under special circumstances, and those provisions would support countries' efforts to address the effects of corruption by sending a message to those responsible for committing Acts of corruption that there will be no place to hide illegal assets in the presence of international cooperation based on the recovery of the proceeds of corruption.

Jurisdiction: The United Nations Convention against Corruption requires both the requesting state party and the requested state to have jurisdiction according to the role entrusted to it in the issue of asset recovery, i.e. the state submitting the recovery request must have jurisdiction over the crime from which the money the subject of the recovery request was obtained from. The acceptance of the requested State Party shall depend on this request. She referred to this agreement condition in paragraph (1) of Article (55), which affirmed that the state party receives a request from another state party for the purpose of confiscating proceeds or property obtained from a crime of corruption that has jurisdiction over it or the tools used to commit this crime if it takes The necessary procedures, that is, the state party receiving the request for confiscation does not accept the request and does not take the necessary measures unless the state party submitting the confiscation request has jurisdiction over the crime from which the money or property to be confiscated was obtained.

Not only that, but also the preparations for the draft United Nations Convention against Corruption confirmed this condition, as it mentioned an explanatory note regarding Paragraph (1/a) of Article (54) of the Convention that the state party does not take the necessary measures to enforce a confiscation order issued by the courts of a state party. Others, by referring it to its competent authority for implementation in the event that this order is issued by a court that does not have jurisdiction over the crime of corruption and the money obtained from it.
Regarding the state party receiving the request for recovery, the agreement requires this state to also have jurisdiction in relation to the legal actions that it takes in relation to the proceeds of crime, property, money or equipment that are the subject of the recovery request. Article (52) devoted to measures to prevent and uncover the transfer of proceeds derived from a crime of corruption stipulated in this agreement, as it required the State Party that received the request to have jurisdiction to take the necessary measures regarding obligating existing financial institutions to take a set of measures in relation to opening Accounts in them, verify the identity of customers, and take reasonable steps to determine the identity of the beneficial owners of the funds deposited in high-value accounts, and to carefully examine the accounts to be opened. The state party can also inform the financial institutions that have jurisdiction over them and upon a request from another state party or on its own initiative, with the identity of natural or legal persons, by carefully examining their accounts. The request cannot undertake these measures if it does not have jurisdiction over the financial institutions that wish to undertake the aforementioned procedures.

Asset recovery through confiscation: The agreement specified three cases of freezing or seizure in paragraph (2) of Article (54), where it stipulated that the State Party, in order to be able to provide mutual legal assistance, upon a request submitted pursuant to Paragraph (2) of Article (55) of the Agreement, must: It shall, according to its national law, the following:

1. The State Party shall take the necessary measures to enable its authorities concerned with the freezing and seizure of property, in accordance with a freezing or seizure order issued by a court or other concerned authority present in the requesting State Party that constitutes a reasonable basis for the requested State Party to believe that there are sufficient reasons to take such measures and that In the end, the mentioned property will be forfeited.

2. The State Party shall take the necessary measures to enable its competent authorities to freeze or seize property and in accordance with a request issued by another State Party that constitutes a reasonable basis for the requested State Party to believe that there are sufficient reasons to take such measures and that these properties will eventually be confiscated.

3. The State party should consider taking additional measures to enable its competent authorities to 
preserve property for the purpose of confiscation based on an arrest or a criminal accusation related to the possession of such property.

An explanatory note regarding Paragraph (2/a) of Article (54) (first case) indicated that the State party can choose between instituting the procedures either for recognition and enforcement of the foreign seizure or freezing order or for the use of this foreign order as a basis for obtaining a seizure or freezing order The reference to the freezing or seizure order stipulated in Paragraph (2/a) of Article (54) should not be interpreted as requiring the enforcement of this order upon its issuance by an authority that does not have jurisdiction or recognition.

It can be said that the invitation is necessary for the drafters of the agreement to amend paragraph (2) of Article (54) to remove the ambiguity or confusion arising in it by clarifying when the request for freezing or seizure should be based on an order issued by a court or other competent authority and when the mere request is sufficient to complete this process It is also necessary to clarify when the request is based on sufficient reasons and what are these reasons, and it is also necessary for them to indicate what the additional measures are, whether for example or exclusively.

The authority governing the confiscation: Confiscation is a complementary punishment, and since it is a punishment, it must be issued by a court ruling, meaning that a person's money cannot be confiscated except by the court hearing a case related to a felony or misdemeanor, and by referring to the United Nations Convention against Corruption, we find that it has violated this rule and deviated from it as it came with a ruling The meaning of the permissibility of a confiscation order issued by a non-judicial authority when defining confiscation in Paragraph (g) of Article (2) as it defined "the term confiscation, which includes forfeiture, where applicable, means the permanent deprivation of property by an order issued by a court or other competent authority." The agreement did not indicate what this authority is, is it the public prosecutor or an administrative body.

\section{Conclusions}

1. Encouraging the states parties to the convention to adopt the mechanisms of international cooperation contained in the convention, and to include them in their domestic laws and bilateral or multilateral agreements that they conclude; Because this cooperation has a great role in reducing corruption.

2. The necessity to develop anti-corruption mechanisms in international agreements to suit the specificity of the country in which they will be applied, with an emphasis on the common goals of all these countries to achieve a high level of good governance and transparency, and not to hinder efforts made for all these countries to join global and regional conventions against corruption .

3. The necessity to establish a special body to combat corruption in every country of the world consisting of persons of credibility and integrity, to give it complete independence and to grant it full powers and immunity in conducting investigations and decision-making and to develop carefully studied strategies that apply the true concept of financial, administrative and judicial control for those who attack public money and those who commit Corruption crimes and for the United Nations Convention against Corruption to be more meaningful and effective.

4. The researcher calls on the Iraqi legislator to enact a law concerned with combating corruption and to allocate part of its articles to the international cooperation mechanisms mentioned in the agreement.

5. Cooperation internationally and regionally to combat corruption in all its forms, and other phenomena related to corruption, such as organized crime and money laundering, and to join and ratify international treaties and charters that achieve combating corruption.

6. Establishing an international court similar to the International Criminal Court, with jurisdiction over corruption crimes and the trial of the most corrupt and theft of public money, including money laundering crimes in third world countries whose people are unable to bring them to justice.

Financial Disclosure: There is no financial disclosure.

Conflict of Interest: None to declare.

Ethical Clearance: All experimental protocols were approved under the University of Babylon and all experiments were carried out in accordance with approved guidelines. 


\section{References}

1. Kevin E. Corruption as a Violation of International Human Rights A Reply to Anne Peters, New York University, School OF Law, Public Law \& Legal Theory Research Paper Series, Working Paper No. 19-45. Published in European Journal of International Law.2019; 29: 1.

2. Peters A. Corruption and Human Rights, Basel Institute on Governance, September 2015: 10.

3. Kinley D. A New Human Right to Freedom From Corruption, Sydney Law School Legal Studies Research. 2014: 8.

4. Mandil NA, Shaaban YA. Research presented to the conference (legislative reform is a path towards good government and combating corruption) held by Al-Naba Foundation for Culture and Media and the University of Kufa/Faculty of Law. 2018

5. Seleem EG. International Cooperation within the Scope of the United Nations Convention Against Corruption, Thesis, College of Law, University of Babylon, 2020; 30

6. Al-Hadithi F. Explanation of the Penal Code, Special Section, Al-Zaman Press, Baghdad, 1996: 75.

7. Al-Durra MA. Explanation of the Penal Code, Special Section, The Legal Library, Baghdad, Revised Edition 2007: 52.

8. Dillon S. Global Corruption: International Law's Counterrevolution, Legal Studies Research Paper Series Research Paper. 2018: 9. 